\title{
Research on College Students' Application Behavior Based on Blackboard System - A Case Study on Business College of Beijing Union University
}

\author{
Li Zheng * and Yinghua Niu \\ Business College of Beijing Union University, Beijing, China \\ li.zheng@buu.edu.cn,yinghua.niu@buu.edu.cn
}

\begin{abstract}
Blackboard system is a network platform that is widely used by Universities and Colleges both at home and abroad. Its role is to broaden students' learning time, space and to assist the students' learning in their class hours and also after their class. Based on the data of a questionnaire on local college students' attitude and behavior on the elearning platform of Blackboard, this thesis presents a generalization and analysis the characteristic of students' e-learning behavior by addressing their three behaviors: Information retrieval and processing behavior, social interaction behavior, and problems solving behavior. The behavioral characteristics of students' application of Blackboard were analyzed in detail. The results showed that: overall, there is no great gender difference in the three aspects, but there are significant differences in different grades. Finally, according to the results of the questionnaire and statistical analysis, several suggestions and advices of curriculum construction based on Blackboard were put forward.
\end{abstract}

Keywords: College students; Blackboard system; e-learning platform; Learning behavior; Questionnaire survey

\section{Introduction}

The advent of the education informationization brings new development opportunities for college curriculum teaching. As the typical representative, the applications of Blackboard Learning System promote the new teaching mode, expand the students' learning time and space, and also provides a good environment for the communication and collaboration between teachers and students. As the world's largest network education solutions and service provider, Blackboard Corporation commit to make full use of the Internet information technology means to improve the experience of teaching and studying in the educational process, provide leading network teaching solutions and services for educational institutions worldwide. More than $70 \%$ of famous universities and colleges in the world adopted it as teaching and learning platform, thus one can see its extremely large market.

In 2005, Blackboard Learning System was led into Beijing Union University. With the support of Blackboard, through 10 years of continuous efforts, the university constructed the integrated system of teaching and learning, realized the sharing platform of high quality teaching resources, built network platform for students' personalized learning, inquiry learning and collaborative learning. At the same time, further exploration and practice of the fusion between Blackboard and college classroom teaching activities were developed in depth.

\footnotetext{
* Corresponding author. Tel: 008610 65940656; Fax: 00861065940655.
} 
However, it was found in the teaching practice that there were great differences among the attitude and behavior of students who use the Blackboard. What aspects did the behavior differences mainly manifest? How they are generated? What are their features? Affected by what factors? How to improve? These problems mentioned above worth our concern and study seriously. On this basis, teachers can understand more deeply about the students' Blackboard application behavior, find the characteristics and regulations, design and provide more targeted course learning resource and its presentation, give better guidance, organization and management of the students' learning process, at last, evaluate the students' learning outcomes in more objective, timely, scientific and effective ways.

\section{The Related Research}

Blackboard application behavior is the learning behavior based on specific network environment. Although it is different from the web-based autonomous learning and distance education, there are many common places in learning contents, learning resources, communication and collaboration among teachers and students. Also, it is quite similar to monitor the learning process of students. So, the theories they according to are the same. This study is based on behavioral science theory, humanistic learning theory, constructivist learning theory and the theory of group dynamics. Due to the limit of this research content and the length of this paper, here focus on the network learning behavior and carry out the literature analysis, so as to provide the theoretical and research basis for the follow-up studies.

The research object of behavioral science is human and human behavior. From the angle of psychology factors such as the needs of the people, desire, motivation and objective, it studies the law of human behavior, especially the relationship between people and people, the individual and collective. And then, with the help of this regularity to forecast and control human behavior, in order to improve work efficiency and achieve organizational goals [1].

The learning behavior is the sum of two-way interactive activities with the surrounding environment for learning outcomes under the guidance of a certain motivation. According to the theory of behavior science, students' learning behavior is not happening independently, but is the interaction results with the surrounding environment, such as teachers, teaching materials, media, teaching references and etc. The predecessors have been done a lot of researches on learning behavior [2-4]. In the guidance of behavior science theory, Wenhui Peng et al [5] gave the definition of network learning behavior by reference to the research results of the previous researchers. They think that it is a distance learning behavior of learners in the environment created by modern information technology and with a new communication mechanism and abundant resources.

The research on network learning behavior are much more abundant, the main focus on the behavior of online learning motivation research, model research, characteristics research, regulation research and etc. Based on these research and analysis, it was found that the main study can be divided into two ways. The first one is through the software tools to track and record analysis operation behavior of learners in network learning. Researchers mainly used the database access records and web server log files to get data and study. The typical representative included K.A. Hummel[3], Qian Huang[6] , Gangshan Fu, Gaihua Wang [7], Li Lv, Yi Zhang [8]and etc.. The second is mostly carried out by interview or questionnaire survey and statistical analysis. The typical representative included Lina Yang et al[9], Yubin Li et al[10], Zhi Ji [11] and etc.. But it is worth to point out that the two research methods are much more concerned about the general sense of the network learning behavior, especially focus on the students' application behavior on the Internet platform to obtain information and carry out distance study. It needs more in-depth and refinement research on students' learning behavior of specific network environment of Blackboard. So, it gives us new research perspectives 
and a new research topic. This thesis is based on the e-learning platform of Blackboard which is widely used in global Universities and Colleges, research the students' learning behavior on this specific platform, explore the hidden rules and characteristics, find the problems, so as to provide targeted advice to those teachers and students who adopted the Blackboard. In this sense, the study is not only important, but also very necessary.

\section{Research Method and Design}

In order to have a better understanding about the college students' Blackboard application behavior characteristics and preferences, explore their learning habits and regular patterns, find the existed problems, guide the students in time, improve the students' learning efficiency and the ability of autonomous learning, the research group adopted a questionnaire survey to collect data and carry out the study.

\subsection{Design basis of the Survey Questionnaire}

At present, there is no complete and universal scale on Blackboard application behavior. Therefore, this research mainly refers to the results of Wenhui Peng [5], Jianwei Zhang [12], Haimin Sun [13], Qinghong Pan [14] and Yubin Li [10], as shown in Table 1.

Table 1. Classification of Network Learning Behaviors

\begin{tabular}{c|c|c|l}
\hline Sequence & Researchers & Classifications & \multicolumn{1}{c}{ Contents } \\
\hline 1 & PENG Wenhui et al & 5 types & $\begin{array}{l}\text { Information retrieval; Information processing; } \\
\text { Information dissemination; Communication and } \\
\text { Problems solving }\end{array}$ \\
\hline 2 & ZHANG Jianwei et al & 3 types & $\begin{array}{l}\text { Information collection and processing; Interpersonal } \\
\text { behavior and Problem solving behavior }\end{array}$ \\
\hline 3 & SUN Haimin & 3 types & $\begin{array}{l}\text { Information processing behavior; Social interaction } \\
\text { behavior and Division of labor behavior }\end{array}$ \\
\hline 5 & PAN Qinghong & 4 types & $\begin{array}{l}\text { Information acquisition; Knowledge processing; } \\
\text { Communication; Evaluation and feedback }\end{array}$ \\
\hline 5 & LI Yubin & 5 types & $\begin{array}{l}\text { Interactive communication; Adherence; Learning } \\
\text { attitude; Online preference; Behavioral flexibility }\end{array}$ \\
\hline
\end{tabular}

According to the model of constructivism theory and above studies, meanwhile considering the combination of teaching and learning, this paper divides the application of Blackboard network behaviors into three levels: Information retrieval and processing behavior, social interaction behavior and problem solving behavior. Among them, information retrieval and processing behavior includes learning behaviors of information acquisition and use, such as information retrieval, download and preservation; social interaction behavior mainly includes learning behaviors of communication and cooperation between teachers and students, students and students etc.; problem solving behavior includes the learning behaviors with characteristics of analysis, application, reflection and innovation, such as finishing the homework, participate in the test, independent learning and so on.

\subsection{Implementation of Questionnaire Survey and Data Processing}

3.2.1. The Object of Study: The survey includes all professional students of the freshman and the junior from Business College of Beijing Union University. We choose 
these two groups due to their representatives. Before entering the university, the freshmen did not have the experiences to use Blackboard to support their own learning systematically. Therefore, this is a new way for them. Their relevant answers to the questionnaire can reflect the most natural and true state. For the junior students, after two years of using, they have been quite familiar with the Blackboard system, and have a better understanding for each function in the system. It can be said that their Blackboard application behavior has been relatively stable. Their learning style is basically reflected in the investigation activities. Therefore, in the investigation of learning behavior for the application of Blackboard system, using the above two groups of students has certain representativeness. Below, Table 2 shows the basic situation of the sample in this questionnaire survey.

Table 2. The Basic Situation of Samples

\begin{tabular}{c|c|c|c}
\hline \multicolumn{2}{c|}{ Classification } & Number of students & percentage \\
\hline \multirow{3}{*}{ Grade } & Freshman & 43 & 49.4 \\
\cline { 2 - 4 } & Junior & 44 & 50.6 \\
\cline { 2 - 4 } & Total & 87 & 100.0 \\
\hline \multirow{3}{*}{ Gender } & Male & 22 & 25.3 \\
\cline { 2 - 4 } & Female & 65 & 74.7 \\
\cline { 2 - 4 } & Total & 87 & 100.0 \\
\hline
\end{tabular}

3.2.2. Research Mode: This study used the questionnaire which is independently designed. The problems in the questionnaire are based on a lot of literature reading and repeated discussions by the related research members. In this study, the questionnaire is divided into two parts: the first part is the survey of the students' natural information, including gender, grade and other information; the second part is the student application behavior based on Blackboard network system, including information retrieval and processing behavior, social interaction behavior and problem solving behavior. The structure of the questionnaire is shown in Table 3.

Table 3. The Structure of the Questionnaire

\begin{tabular}{|c|c|c|c|c|}
\hline \multirow[b]{2}{*}{$\begin{array}{c}\text { Investigation } \\
\text { dimension }\end{array}$} & \multirow{2}{*}{$\begin{array}{c}\text { The first part } \\
\text { The basic } \\
\text { information of } \\
\text { respondents }\end{array}$} & \multicolumn{3}{|c|}{ The second part } \\
\hline & & $\begin{array}{c}\text { information retrieval } \\
\text { and processing } \\
\text { behavior }\end{array}$ & $\begin{array}{l}\text { social interaction } \\
\text { behavior }\end{array}$ & $\begin{array}{l}\text { problem solving } \\
\text { behavior }\end{array}$ \\
\hline Main content items & $\begin{array}{l}\text { including gender, } \\
\text { grade and other } \\
\text { information }\end{array}$ & $\begin{array}{l}\text { Including access to } \\
\text { learning materials, } \\
\text { browse class video, } \\
\text { view the calendar, } \\
\text { syllabus, contents on } \\
\text { BB and so on }\end{array}$ & $\begin{array}{l}\text { Including the use } \\
\text { of Blackboard to } \\
\text { consult teachers, } \\
\text { discuss among } \\
\text { teachers and } \\
\text { students, actively } \\
\text { speakers and so on }\end{array}$ & $\begin{array}{l}\text { Including the use } \\
\text { of Blackboard to } \\
\text { preview, review, } \\
\text { do exercises, tests, } \\
\text { case analysis and } \\
\text { so on }\end{array}$ \\
\hline
\end{tabular}

This study was conducted in the form of questionnaire survey. The respondents are the students from Business College of Beijing Union University. A total of 100 questionnaires were distributed and 94 complete was collected, the rate of recovery is $94 \%$. In the process of data sorting, excluding 7 copies of various problems in the questionnaire, we got 87 valid questionnaires, the effective rate of recovery is $92.6 \%$. For the individual problem which is not standard answer, we adopted the way of handling with missing values.

3.2.3. Reliability and Validity Analysis: In the questionnaire, we basically adopted five levels Likert scale to test the students' perception and application behavior based on 
Blackboard in addition to some individual items. We use 1-5 to represent "totally agree" , "agree", "not sure" , "don't agree" and "disagree completely" respectively. In addition, single choice items were used in the questionnaire. The results were classified and analyzed with statistics software Spss13.0. The reliability analysis and validity analysis of the questionnaire are shown in Table 4 Table 5.

Table 4. Reliability Analysis of the Questionnaire

\begin{tabular}{l|c|c|c}
\hline \multicolumn{1}{c|}{ Dimensions } & Alpha coefficient & Items & Total sample \\
\hline The whole questionnaire & 0.919 & 26 & 85 \\
\hline Information retrieval and processing behavior & 0.820 & 8 & 87 \\
\hline Social interaction behavior & 0.714 & 6 & 86 \\
\hline Problem solving behavior & 0.836 & 12 & 86 \\
\hline
\end{tabular}

It can be seen from Table 4, overall, the questionnaire has a high homogeneity. The Alpha coefficient is 0.919 , the coefficient of students' application behavior in the three dimensions based on the Blackboard system are all higher than 0.7. This indicates that the questionnaire has good consistency and stability.

Table 5. Validity Analysis of the Questionnaire

\begin{tabular}{|c|c|c|c|c|c|}
\hline & & Total & $\begin{array}{c}\text { Information } \\
\text { retrieval and } \\
\text { processing }\end{array}$ & $\begin{array}{c}\text { Social } \\
\text { interaction }\end{array}$ & $\begin{array}{c}\text { Problem } \\
\text { solving }\end{array}$ \\
\hline \multirow{2}{*}{ Total } & $\begin{array}{c}\text { The Pearson correlation } \\
\text { coefficient }\end{array}$ & 1 & & & \\
\hline & Significance (bilateral) & & & & \\
\hline \multirow{2}{*}{$\begin{array}{l}\text { Information } \\
\text { retrieval and } \\
\text { processing }\end{array}$} & $\begin{array}{c}\text { The Pearson correlation } \\
\text { coefficient }\end{array}$ & $0.900 * *$ & 1 & & \\
\hline & Significance (bilateral) & 0.000 & & & \\
\hline \multirow{2}{*}{ Social interaction } & $\begin{array}{c}\text { The Pearson correlation } \\
\text { coefficient }\end{array}$ & $0.847 * *$ & 0.635 & 1 & \\
\hline & Significance (bilateral) & 0.000 & 0.000 & & \\
\hline \multirow[t]{2}{*}{ Problem solving } & $\begin{array}{c}\text { The Pearson correlation } \\
\text { coefficient }\end{array}$ & $0.955^{* *}$ & 0.791 & 0.744 & 1 \\
\hline & Significance (bilateral) & 0.000 & 0.000 & 0.000 & \\
\hline
\end{tabular}

*. Represent at the significant level of 0.05 was significant (bilateral).

**. Represent at the significant level of 0.01 was significant (bilateral).

It can be seen from Table 5, all items and measuring subject are significantly correlated (Pearson correlation coefficient is greater than 0.8, while the conspicuousness is less than 0.05). It indicates that the questionnaire has good content validity.

\section{Study results and Analysis}

The following are analyzed in detail from the students' information retrieval and processing behavior, social interaction behavior and problem solving behavior while they learn with Blackboard.

\subsection{Information Retrieval and Processing Behavior}

4.1.1. The Basic Characteristics: It can be learned from the survey that the students pay close attention to the text type resources among various network resources when they $\log$ on the Blackboard. It shows that $86.2 \%$ of the students will get learning courseware and other materials offered by the lecturers from Blackboard; about $70.9 \%$ students will browse other literature references. Video and other types of resources has not been 
particularly favored by the students, only $32.2 \%$ of the students often watch the teachers' lecture video or other videos.

In addition, the students' retrieval and processing contents mainly depend on the resources provided by the teachers. The statistical result shows, $72.4 \%$ of the students consider that the resources are very rich. About the study materials' acquisition channel, $86.2 \%$ of the students said the main access is through the Blackboard; $77 \%$ of the students hope to be able to enter other courses' websites in the university, browse and learn from those courses; Only $57.5 \%$ of the students said that in addition to the Blackboard, they also regularly logged on other websites to download some useful learning materials.

4.1.2. The Influence of Gender on Retrieval and Processing Behavior: The results of the survey show that, gender has no significant effect on Blackboard information retrieval and processing behavior. Generally speaking, the gender is one of the factors leading to individual differences in behavior. It was found in references [15-17] that boys and girls have great differences in their information retrieval behavior while they surf the web. But this survey showed that, there is no significant difference between male and female students in their Blackboard information retrieval and processing behavior, only with one exception. That is, more females than males tend to check the teaching calendar in order to understand the course schedule. Table 6 shows the independent samples t-test results of the respondents' information retrieval and processing behavior with gender.

Table 6. Independent Samples T-test Results of the Respondents' Information Retrieval and Processing Behavior with Gender

\begin{tabular}{|c|c|c|c|c|}
\hline Dependent variable & Gender & $\begin{array}{l}\text { Mean } \\
\text { value }\end{array}$ & T value & $\mathbf{p} \leq$ \\
\hline \multirow{2}{*}{$\begin{array}{l}\text { I often use Blackboard to access learning materials } \\
\text { (such as the teacher's courseware). }\end{array}$} & Male & 1.91 & \multirow{2}{*}{0.159} & \multirow{2}{*}{0.874} \\
\hline & Female & 1.88 & & \\
\hline \multirow{2}{*}{$\begin{array}{l}\text { I often use Blackboard to watch teachers' lecture } \\
\text { video and etc. }\end{array}$} & Male & 3.18 & \multirow{2}{*}{0.790} & \multirow{2}{*}{0.432} \\
\hline & Female & 2.97 & & \\
\hline \multirow{2}{*}{$\begin{array}{l}\text { I often use Blackboard to look over the teaching } \\
\text { calendar in order to understand the curriculum } \\
\text { schedule. } * *\end{array}$} & Male & 3.14 & \multirow{2}{*}{2.783} & \multirow{2}{*}{0.007} \\
\hline & Female & 2.49 & & \\
\hline \multirow{2}{*}{$\begin{array}{l}\text { I often use Blackboard to check the syllabus so as } \\
\text { to understand the basic requirements of the } \\
\text { curriculum and the related contents. }\end{array}$} & Male & 2.86 & \multirow{2}{*}{1.649} & \multirow{2}{*}{0.103} \\
\hline & Female & 2.48 & & \\
\hline \multirow{2}{*}{$\begin{array}{l}\text { I often use Blackboard to view all kinds of } \\
\text { literature provided by teachers. }\end{array}$} & Male & 2.59 & \multirow{2}{*}{1.601} & \multirow{2}{*}{0.120} \\
\hline & Female & 2.18 & & \\
\hline \multirow{2}{*}{$\begin{array}{l}\text { I hope to be able to enter other courses' website in } \\
\text { order to browse and take in some useful contents to } \\
\text { me. }\end{array}$} & Male & 2.32 & \multirow{2}{*}{0.952} & \multirow{2}{*}{0.350} \\
\hline & Female & 2.03 & & \\
\hline \multirow{2}{*}{$\begin{array}{l}\text { The application of Blackboard will be of benefit for } \\
\text { my repeated learning the difficulties and key } \\
\text { contents of the course. }\end{array}$} & Male & 2.68 & \multirow{2}{*}{1.018} & \multirow{2}{*}{0.311} \\
\hline & Female & 2.45 & & \\
\hline \multirow{2}{*}{$\begin{array}{l}\text { In addition to Blackboard, I often log on other } \\
\text { websites to download the learning materials. }\end{array}$} & Male & 2.64 & \multirow{2}{*}{0.212} & \multirow{2}{*}{0.832} \\
\hline & Female & 2.58 & & \\
\hline
\end{tabular}

Note: Taking the significant level of $\alpha=0.05$. The dependent variables with $(* *)$ represented that gender had a significant effect on it, while the dependent variables without $(* *)$ represented that gender had no significant effects on it.

4.1.3. The Influence of Grade on Retrieval and Processing Behavior: The survey result indicated that grade had a significant influence on Blackboard information retrieval and processing behavior. Through the comparative analysis of student information retrieval behavior between the freshmen and the junior, it was found that there is a 
significant difference in behavior such as accessing to learning materials, checking the syllabus, viewing the various documents etc. between students in different grades. The result was shown in Table 7. It showed that the freshmen are mainly concentrated in the Blackboard application to complete the homework assigned by the teachers and other basic tasks, whereas the junior students are more inclined to some extended reading and learning in addition to the completion of the prescribed learning tasks, so their use of other Blackboard resources are much more efficient and extensive.

\section{Table 7. Independent Samples T-test Results of the Respondents' Information Retrieval and Processing Behavior with Grade}

\begin{tabular}{|c|c|c|c|c|}
\hline Dependent variable & Grade & $\begin{array}{c}\text { Mean } \\
\text { value }\end{array}$ & T value & $\mathbf{p} \leq$ \\
\hline \multirow{2}{*}{$\begin{array}{l}\text { I often use Blackboard to access learning materials } \\
\text { (such as the teacher's courseware). ** }\end{array}$} & Freshmen & 2.12 & \multirow{2}{*}{2.718} & \multirow{2}{*}{0.008} \\
\hline & Junior & 1.66 & & \\
\hline \multirow{2}{*}{$\begin{array}{l}\text { I often use Blackboard to watch teachers' lecture } \\
\text { video and } \text { etc.. }\end{array}$} & Freshmen & 3.23 & \multirow{2}{*}{1.798} & \multirow{2}{*}{0.076} \\
\hline & Junior & 2.82 & & \\
\hline \multirow{2}{*}{$\begin{array}{l}\text { I often use Blackboard to look over the teaching } \\
\text { calendar in order to understand the curriculum } \\
\text { schedule. }\end{array}$} & Freshmen & 2.86 & \multirow{2}{*}{1.975} & \multirow{2}{*}{0.051} \\
\hline & Junior & 2.45 & & \\
\hline \multirow{2}{*}{$\begin{array}{l}\text { I often use Blackboard to check the syllabus so as } \\
\text { to understand the basic requirements of the } \\
\text { curriculum and the related contents. ** }\end{array}$} & Freshmen & 2.91 & \multirow{2}{*}{3.379} & \multirow{2}{*}{0.001} \\
\hline & Junior & 2.25 & & \\
\hline \multirow{2}{*}{$\begin{array}{l}\text { I often use Blackboard to view all kinds of } \\
\text { literature provided by teachers. } * *\end{array}$} & Freshmen & 2.58 & \multirow{2}{*}{3.197} & \multirow{2}{*}{0.002} \\
\hline & Junior & 2.00 & & \\
\hline \multirow{2}{*}{$\begin{array}{l}\text { I hope to be able to enter other courses' website in } \\
\text { order to browse and take in some useful contents to } \\
\text { me. }\end{array}$} & Freshmen & 2.12 & \multirow{2}{*}{0.129} & \multirow{2}{*}{0.897} \\
\hline & Junior & 2.09 & & \\
\hline \multirow{2}{*}{$\begin{array}{l}\text { The application of Blackboard will be of benefit } \\
\text { for my repeated learning the difficulties and key } \\
\text { contents of the course. }\end{array}$} & Freshmen & 2.67 & \multirow{2}{*}{1.669} & \multirow{2}{*}{0.099} \\
\hline & Junior & 2.34 & & \\
\hline \multirow{2}{*}{$\begin{array}{l}\text { In addition to Blackboard, I often log on other } \\
\text { websites to download the learning materials. }\end{array}$} & Freshmen & 2.65 & \multirow{2}{*}{0.500} & \multirow{2}{*}{0.618} \\
\hline & Junior & 2.55 & & \\
\hline
\end{tabular}

Note: Taking the significant level of $\alpha=0.05$. The dependent variables with $(* *)$ represented that grade had a significant effect on it, while the dependent variables without $(* *)$ represented that grade had no significant effects on it.

\subsection{Social Interaction Behavior}

4.2.1. The Basic Characteristics: It can be learned from the survey results, the majority of students still prefer the traditional face-to-face learning behavior in their learning process. The survey shows that $63.2 \%$ of the students like traditional face-to-face consultation problem to teachers, only $36.8 \%$ of the students are more likely to ask questions through the Blackboard.

In social interaction behavior, the individual differences of students to actively participate in the interaction are quite large. The investigation shows that $40.2 \%$ of students are active participants, they often communicate with teachers and their classmates through Blackboard; $26.7 \%$ of the students are general participants; and $32.2 \%$ of the students said they rarely participate in the Blackboard discussion.

Although the positive participants account for only $40 \%$, the majority of students are very identify with the Blackboard discussion board. $65.5 \%$ of the students think that the application of Blackboard help them to share information and intelligence between teachers and students; $55.1 \%$ of the students think that the application of Blackboard is much more convenient for them to communicate with teachers in their learning process. 
In particular, $59.7 \%$ of the students hope that teachers can allow them to participate in the Blackboard construction and management. This shows the students' active attitude for participation in the course construction and strong desire to realize their self-value.

4.2.2. The Influence of Gender on Students' Social Interaction Behavior: The investigation result indicated that, overall, the gender in the interactive behavior of Blackboard application has small significant difference, as shown in Table 8. But the girls' average score is generally lower than that of the boys, illustrates that the girls' enthusiasm in interactive behavior is higher than boys. Furthermore, male and female students show significant difference in the active speaking, fully expression of their own views, hope to become the Blackboard discussion board moderator, and undertaking the corresponding tasks. The survey shows that the girls have higher enthusiasm and stronger sense of participation than the boys.

Table 8. Independent Samples T-test Results of the Respondents' Social Interaction Behavior with Gender

\begin{tabular}{|c|c|c|c|c|}
\hline Dependent variable & Gender & $\begin{array}{c}\text { Mean } \\
\text { value }\end{array}$ & T value & $\mathbf{p} \leq$ \\
\hline \multirow{2}{*}{$\begin{array}{l}\text { I often use Blackboard to communicate with } \\
\text { teachers or classmates. }\end{array}$} & Male & 3.05 & \multirow{2}{*}{1.040} & \multirow{2}{*}{0.301} \\
\hline & Female & 2.77 & & \\
\hline \multirow{2}{*}{$\begin{array}{l}\text { For the Blackboard discussion topics, I will always } \\
\text { speak actively, fully express my own point of } \\
\text { view.** }\end{array}$} & Male & 3.23 & \multirow{2}{*}{2.144} & \multirow{2}{*}{0.035} \\
\hline & Female & 2.68 & & \\
\hline \multirow{2}{*}{$\begin{array}{l}\text { I hope to become a Blackboard discussion board } \\
\text { moderator, and undertake the corresponding } \\
\text { tasks.** }\end{array}$} & Male & 3.41 & \multirow{2}{*}{2.274} & \multirow{2}{*}{0.026} \\
\hline & Female & 2.80 & & \\
\hline \multirow{2}{*}{$\begin{array}{l}\text { I hope teachers can let the students participate in } \\
\text { course website construction and management, so as } \\
\text { to improve students' deeper engagement. }\end{array}$} & Male & 2.27 & \multirow{2}{*}{-0.762} & \multirow{2}{*}{0.448} \\
\hline & Female & 2.45 & & \\
\hline \multirow{2}{*}{$\begin{array}{l}\text { Application of Blackboard help to share } \\
\text { information and intelligence between teachers and } \\
\text { students. }\end{array}$} & Male & 2.32 & \multirow{2}{*}{-0.155} & \multirow{2}{*}{0.877} \\
\hline & Female & 2.35 & & \\
\hline \multirow{2}{*}{$\begin{array}{l}\text { Application of Blackboard is much more } \\
\text { convenient for me to discuss and communicate } \\
\text { with teachers and classmates. }\end{array}$} & Male & 2.73 & \multirow{2}{*}{1.105} & \multirow{2}{*}{0.279} \\
\hline & Female & 2.45 & & \\
\hline
\end{tabular}

Note: Taking the significant level of $\alpha=0.05$. The dependent variables with $(* *)$ represented that gender had a significant effect on it, while the dependent variables without $(* *)$ represented that gender had no significant effects on it.

4.2.3. The Influence of Grade on Students' Social Interaction Behavior: Through the comparative analysis of student social interaction behavior between the freshmen and the junior, it was found that there had a significant difference between the two grade students in their communication with teachers and classmates, express and exchange their opinions. The results showed that the freshmen were not active in their social interaction. The possible reasons include: Freshmen students are not familiar with each other; they have not yet formed into fixed learning groups; or they may not familiar with mutual collaboration and learning mode and so on. Table 9 shows the results of the independent samples t-test values of the respondents' social interaction behavior with grade. 
Table 9. Independent Samples T-test Results of the Respondents' Social Interaction Behavior with Grade

\begin{tabular}{|c|c|c|c|c|}
\hline Dependent variable & Grade & $\begin{array}{l}\text { Mean } \\
\text { value }\end{array}$ & T value & $\mathbf{p} \leq$ \\
\hline \multirow{2}{*}{$\begin{array}{l}\text { I often use Blackboard to communicate with teachers } \\
\text { or classmates. } * *\end{array}$} & Freshmen & 3.23 & \multirow{2}{*}{3.595} & \multirow{2}{*}{0.001} \\
\hline & Junior & 2.45 & & \\
\hline \multirow{2}{*}{$\begin{array}{l}\text { For the Blackboard discussion topics, I will always } \\
\text { speak actively, fully express my own point of view. } \\
* *\end{array}$} & Freshmen & 3.23 & \multirow{2}{*}{3.886} & \multirow{2}{*}{0.000} \\
\hline & Junior & 2.41 & & \\
\hline \multirow{2}{*}{$\begin{array}{l}\text { I hope to become a Blackboard discussion board } \\
\text { moderator, and undertake the corresponding tasks. }\end{array}$} & Freshmen & 3.00 & \multirow{2}{*}{0.385} & \multirow{2}{*}{0.701} \\
\hline & Junior & 2.91 & & \\
\hline \multirow{2}{*}{$\begin{array}{l}\text { I hope teachers can let the students participate in the } \\
\text { course website construction and management, so as to } \\
\text { improve students' deeper engagement. }\end{array}$} & Freshmen & 2.47 & \multirow{2}{*}{0.624} & \multirow{2}{*}{0.534} \\
\hline & Junior & 2.34 & & \\
\hline \multirow{2}{*}{$\begin{array}{l}\text { Application of Blackboard helps to share information } \\
\text { and intelligence between teachers and students. }\end{array}$} & Freshmen & 2.35 & \multirow{2}{*}{0.040} & \multirow{2}{*}{0.968} \\
\hline & Junior & 2.34 & & \\
\hline \multirow{2}{*}{$\begin{array}{l}\text { Application of Blackboard is much more convenient } \\
\text { for me to discuss and communicate with teachers and } \\
\text { classmates. }\end{array}$} & Freshmen & 2.63 & \multirow{2}{*}{1.228} & \multirow{2}{*}{0.223} \\
\hline & Junior & 2.41 & & \\
\hline
\end{tabular}

Note: Taking the significant level of $\alpha=0.05$. The dependent variables with $(* *)$ represented that grade had a significant effect on it, while the dependent variables without $(* *)$ represented that grade had no significant effects on it.

\subsection{Problem Solving Behavior}

The ultimate goal of teaching is to cultivate students' autonomous learning ability, and solve problems creatively according to the actual situation. In order to understand the students' autonomous learning and problem solving behavior, the corresponding problems are provided in this questionnaire survey. The following is the statistical analysis result to these problems.

4.3.1. The Basic Characteristics: It can be learned from the survey results that the students spend much more time to review than preview through Blackboard. Among them, $68.9 \%$ of the students often use Blackboard to review what they have learned in their class, but only $45.9 \%$ of the students often use Blackboard to preview.

Secondly, the utilization rate of Blackboard exercises and tests module are not high, only $49.4 \%$ of the students often use the test section. Nevertheless, there are still $73.5 \%$ of the students hope the Blackboard can display real-time scores after they have finished their online test; $83.9 \%$ of the students hope that the correct answer and explanation of the answer can be displayed in a timely manner.

In addition, according to the results of the survey, students' learning behavior is over reliance on their teachers. $62.7 \%$ of the students said they often download and study the case analysis provided by the teacher through Blackboard; $77.9 \%$ of the students often use Blackboard exercise section and test section to learn and practice after their class. According to the interviews with some of the students, they pay less attention on other online resources except a variety of resources provided by teachers in the Blackboard, thus the utilization rate of other resources is low. This can be corroborated by the results from our survey. It was found that $27.5 \%$ of the students know and have used the resources from China university video open class; $31 \%$ of the students understand and have surfed Chinese university resources sharing class; $34.4 \%$ of the students understand and willing to use MOOC (massive open online courses) for their autonomous learning. Obviously, 
for the respondents, their autonomy and enthusiasm in learning still need to be further improved.

4.3.2. The Influence of Gender on Students' Problem Solving Behavior: It can be seen from Table 10 that gender had no obvious effects on students' problem solving behavior. There were no significant differences between male and female students in each survey items.

\section{Table 10. Independent Samples T-test Results of the Respondents' Problem Solving Behavior with Gender}

\begin{tabular}{|c|c|c|c|c|}
\hline Dependent variable & Gender & $\begin{array}{l}\text { Mean } \\
\text { value }\end{array}$ & T value & $\mathbf{p} \leq$ \\
\hline \multirow{2}{*}{ I often do curriculum preview through Blackboard. } & Male & 3.05 & \multirow{2}{*}{1.315} & \multirow{2}{*}{0.192} \\
\hline & Female & 2.72 & & \\
\hline \multirow{2}{*}{ I often do curriculum review through Blackboard. } & Male & 2.36 & \multirow{2}{*}{0.272} & \multirow{2}{*}{0.788} \\
\hline & Female & 2.28 & & \\
\hline \multirow{2}{*}{ I often do on-line tests through Blackboard. } & Male & 2.68 & \multirow{2}{*}{0.121} & \multirow{2}{*}{0.905} \\
\hline & Female & 2.65 & & \\
\hline \multirow{2}{*}{$\begin{array}{l}\text { I often study the case analysis provided by teachers } \\
\text { through Blackboard. }\end{array}$} & Male & 2.36 & \multirow{2}{*}{-0.237} & \multirow{2}{*}{0.813} \\
\hline & Female & 2.42 & & \\
\hline \multirow{2}{*}{$\begin{array}{l}\text { I often do homework and exercises through } \\
\text { Blackboard after class. }\end{array}$} & Male & 2.14 & \multirow{2}{*}{0.558} & \multirow{2}{*}{0.578} \\
\hline & Female & 2.02 & & \\
\hline \multirow{2}{*}{$\begin{array}{l}\text { I hope that after the online test the score shall be } \\
\text { displayed at once. }\end{array}$} & Male & 2.41 & \multirow{2}{*}{1.020} & \multirow{2}{*}{0.316} \\
\hline & Female & 2.12 & & \\
\hline \multirow{2}{*}{$\begin{array}{l}\text { I hope that after the online test the correct answer and } \\
\text { explanation shall be displayed at once. }\end{array}$} & Male & 1.82 & \multirow{2}{*}{-0.747} & \multirow{2}{*}{0.457} \\
\hline & Female & 1.95 & & \\
\hline \multirow{2}{*}{$\begin{array}{l}\text { The application of Blackboard is much more helpful } \\
\text { to my autonomous learning and research learning. }\end{array}$} & Male & 2.32 & \multirow{2}{*}{0.676} & \multirow{2}{*}{0.504} \\
\hline & Female & 2.15 & & \\
\hline \multirow{2}{*}{$\begin{array}{l}\text { The application of Blackboard is much more helpful } \\
\text { to promote the evaluation and reflection on our } \\
\text { learning results. }\end{array}$} & Male & 2.32 & \multirow{2}{*}{-0.019} & \multirow{2}{*}{0.985} \\
\hline & Female & 2.32 & & \\
\hline \multirow{2}{*}{$\begin{array}{l}\text { I know and have used the resources from China } \\
\text { university video open class. }\end{array}$} & Male & 3.09 & \multirow{2}{*}{0.112} & \multirow{2}{*}{0.911} \\
\hline & Female & 3.06 & & \\
\hline \multirow{2}{*}{$\begin{array}{l}\text { I know and have used the website of Chinese } \\
\text { university resources sharing class. }\end{array}$} & Male & 3.05 & \multirow{2}{*}{-0.063} & \multirow{2}{*}{0.950} \\
\hline & Female & 3.06 & & \\
\hline \multirow{2}{*}{$\begin{array}{l}\text { I understand and willing to use MOOC (massive open } \\
\text { online courses). }\end{array}$} & Male & 3.32 & 1545 & 0126 \\
\hline & Female & 2.92 & 1.545 & 0.120 \\
\hline
\end{tabular}

4.3.3. The Influence of Grade on Students' Problem Solving Behavior: Through the comparative analysis of the two different grade students' problem solving behavior, it can be found that the junior students' problem solving behavior performance is much more prominent than the freshmen, as shown in Table 11. The results showed that the junior students present more characteristics of problem solving behavior, such as preview, review, do exercises, test, case analysis and research study, whereas the freshmen's behavior only focused on some basic contents, for example, finishing the homework or doing exercises. What they lack is to carry out further independent study and research study through the Blackboard. 
Table 11. Independent Samples T-test Results of the Respondents' Problem Solving Behavior with Grade

\begin{tabular}{|c|c|c|c|c|}
\hline Dependent variable & Grade & $\begin{array}{l}\text { Mean } \\
\text { value }\end{array}$ & T value & $\mathbf{p} \leq$ \\
\hline \multirow{2}{*}{ I often do curriculum preview through Blackboard. ** } & Freshmen & 3.21 & \multirow{2}{*}{4.062} & \multirow{2}{*}{0.000} \\
\hline & Junior & 2.41 & & \\
\hline \multirow{2}{*}{ I often do curriculum review through Blackboard. $* *$} & Freshmen & 2.72 & \multirow{2}{*}{4.017} & \multirow{2}{*}{0.000} \\
\hline & Junior & 1.89 & & \\
\hline \multirow{2}{*}{ I often do on-line tests through Blackboard. ** } & Freshmen & 2.95 & \multirow{2}{*}{2.870} & \multirow{2}{*}{0.005} \\
\hline & Junior & 2.36 & & \\
\hline \multirow{2}{*}{$\begin{array}{l}\text { I often study the case analysis provided by teachers } \\
\text { through Blackboard. ** }\end{array}$} & Freshmen & 2.64 & \multirow{2}{*}{2.200} & \multirow{2}{*}{0.031} \\
\hline & Junior & 2.18 & & \\
\hline \multirow{2}{*}{$\begin{array}{l}\text { I often do homework and exercises through } \\
\text { Blackboard after class. }\end{array}$} & Freshmen & 2.12 & \multirow{2}{*}{0.739} & \multirow{2}{*}{0.462} \\
\hline & Junior & 1.98 & & \\
\hline \multirow{2}{*}{$\begin{array}{l}\text { I hope that after the online test the score shall be } \\
\text { displayed at once. }\end{array}$} & Freshmen & 2.28 & \multirow{2}{*}{0.810} & \multirow{2}{*}{0.420} \\
\hline & Junior & 2.11 & & \\
\hline \multirow{2}{*}{$\begin{array}{l}\text { I hope that after the online test the correct answer and } \\
\text { explanation shall be displayed at once. }\end{array}$} & Freshmen & 1.88 & \multirow{2}{*}{-0.447} & \multirow{2}{*}{0.656} \\
\hline & Junior & 1.95 & & \\
\hline \multirow{2}{*}{$\begin{array}{l}\text { The application of Blackboard is much more helpful to } \\
\text { my autonomous learning and research learning. }\end{array}$} & Freshmen & 2.33 & \multirow{2}{*}{1.398} & \multirow{2}{*}{0.166} \\
\hline & Junior & 2.07 & & \\
\hline \multirow{2}{*}{$\begin{array}{l}\text { The application of Blackboard is much more helpful to } \\
\text { promote the evaluation and reflection on our learning } \\
\text { results. }\end{array}$} & Freshmen & 2.40 & \multirow{2}{*}{0.766} & \multirow{2}{*}{0.446} \\
\hline & Junior & 2.25 & & \\
\hline \multirow{2}{*}{$\begin{array}{l}\text { I know and have used the resources from China } \\
\text { university video open class. }\end{array}$} & Freshmen & 3.00 & \multirow{2}{*}{-0.601} & \multirow{2}{*}{0.549} \\
\hline & Junior & 3.14 & & \\
\hline \multirow{2}{*}{$\begin{array}{l}\text { I know and have used the website of Chinese } \\
\text { university resources sharing class. }\end{array}$} & Freshmen & 2.95 & \multirow{2}{*}{-0.933} & \multirow{2}{*}{0.354} \\
\hline & Junior & 3.16 & & \\
\hline \multirow{2}{*}{$\begin{array}{l}\text { I understand and willing to use MOOC (massive open } \\
\text { online courses). }\end{array}$} & Freshmen & 3.19 & 1448 & 0151 \\
\hline & Junior & 2.86 & 1.448 & 0.151 \\
\hline
\end{tabular}

Note: Taking the significant level of $\alpha=0.05$. The dependent variables with $(* *)$ represented that grade had a significant effect on it, while the dependent variables without $(* *)$ represented that grade had no significant effects on it.

\section{4. Summary of the Application Behavior based on the Blackboard}

From Table 12 and Table 13 we can see that, in overall, there have no significant differences about the three dimensions of Blackboard application behavior in gender. But there were significant differences between their grades. The results demonstrate that the junior students have obvious advantages in all aspects of the application abilities than the lower grade students.

\section{Table 12. Independent Samples T-test Results of the Respondents' Application Behavior based on Blackboard with Gender}

\begin{tabular}{c|c|c|c|c}
\hline \multirow{2}{*}{ Dependent variable } & Gender & Mean value & T value & p $\leq$ \\
\hline \multirow{2}{*}{ Information retrieval and processing behavior } & Male & 21.3182 & \multirow{2}{*}{1.842} & 0.069 \\
\cline { 2 - 3 } & Female & 19.0615 & & \\
\hline
\end{tabular}




\begin{tabular}{l|c|c|c|c}
\hline \multirow{2}{*}{ Social interaction behavior } & Male & 17.0000 & \multirow{2}{*}{1.656} & \multirow{2}{*}{0.101} \\
\cline { 2 - 3 } & Female & 15.4462 & & \\
\hline \multirow{2}{*}{ Problem solving behavior } & Male & 30.9091 & \multirow{2}{*}{0.746} & \multirow{2}{*}{0.458} \\
\cline { 2 - 3 } & Female & 29.6462 & \\
\hline
\end{tabular}

Table 13. Independent Samples T-test Results of the Respondents' Application Behavior based on Blackboard with Grade

\begin{tabular}{|c|c|c|c|c|}
\hline Dependent variable & Gender & Mean value & T value & $\mathbf{p} \leq$ \\
\hline \multirow{2}{*}{$\begin{array}{l}\text { Information retrieval and processing behavior } \\
* *\end{array}$} & Freshmen & 21.1395 & \multirow{2}{*}{2.857} & \multirow{2}{*}{0.006} \\
\hline & Junior & 18.1591 & & \\
\hline \multirow{2}{*}{ Social interaction behavior $* *$} & Freshmen & 16.9070 & \multirow{2}{*}{2.651} & \multirow{2}{*}{0.010} \\
\hline & Junior & 14.7955 & & \\
\hline \multirow{2}{*}{ Problem solving behavior $* *$} & Freshmen & 31.6047 & \multirow{2}{*}{2.261} & \multirow{2}{*}{0.026} \\
\hline & Junior & 28.3636 & & \\
\hline
\end{tabular}

Note: Taking the significant level of $\alpha=0.05$. The dependent variables with (**) represented that grade had a significant effect on it, while the dependent variables without $(* *)$ represented that grade had no significant effects on it.

\section{Conclusions and Suggestions}

Based on the questionnaire survey of college students' Blackboard application behavior and a more in-depth study, the following conclusions could be drawn. On this basis, several suggestions to the curriculum construction based on Blackboard were put forward.

\subsection{About the Information Retrieval and Processing Behavior}

The information retrieval and processing behavior of students is text type resources oriented, and the contents mostly depend on the materials provided by teachers. The students' independent and inquiry learning abilities are weak, their information retrieval and processing skills need to be improved.

In the construction of Blackboard curriculum, many teachers always think audio, video, animation and other multimedia types of resources will attract the attention of students than the text type resources. Thus this kind of multimedia resources will be more popular with the students. Moreover, the evaluation of Blackboard video resource by the domestic education departments has always been one of the important contents. But in fact, the actual situation is turning against it. The survey shows, the text type resource is the most concern type when students login the Blackboard. The reason might be include two aspects. The first one is, the video and audio resources have large data quantity, it will spend long time to download or open because of the slow speed, and so many students lose their patience to use it. The second one is, due to the restrictions of information technology and the application ability of teachers, many multimedia resources did not have a good presentation of teaching contents, the pertinence and consistency with the teaching contents is weaker than the text resources, which affected the students' enthusiasm to use the video and audio resources actively.

This study shows that students' gender had no significant effect on their information retrieval and processing behavior, but girls are obviously more inclined to often look through teaching calendar, so as to understand the curriculum schedule. This is coinciding with girls' characteristics such as careful, cautious, and willing to plan in advance and so 
on. In the grade aspect, it shows significant differences about information retrieval and processing behavior between students from different grades. The lower grade students' learning is more passive, their information retrieval and processing behavior is much more limited by the resources provided by school teachers. Junior students will do some extended learning and self-controlled study in addition to the completion of the provisions of the learning task. But from the point of using network resources, all students had strong dependence on the teachers, their self-motivation, independent and research learning is still exists a large gap.

According to the statistical data of the college students' information retrieval and processing behavior, the suggestions are: teachers should continue to provide high quality text type resources. On the other hand, they should also analyze the reasons for limiting video and audio resources widely used by students. On the basis of improving the level of modern educational technology application, referencing flipped classroom experience, cutting teaching contents of video type resources into small video clips, thus improving the effectiveness of video resource utilization. In addition, in the process of Blackboard website construction, teachers should increase the corresponding extension of learning resources and mission requirements consciously according to gender characteristics and grade characteristics, guide the students' autonomous learning, and cultivate the students' good learning habits.

\subsection{About the Social Interaction Behavior}

Although the students now belong to the "Digital Native Generation", it is natural for them to accept new technology, the survey reveals that in the process of learning they still tend to communicate and consult with their teachers or classmates face-to-face. The study results also show that carrying out discussion and cooperation via Blackboard is very approved by the students. Moreover, they are quite agreed with the way of Crowdsourcing to share information, wisdom and solve problems.

Through this investigation, the research group has clarified a misunderstanding of communication and cooperation between teachers and students, students and students. Although the introduction of new technology, such as micro-blog, micro-message, mobile Internet, adds many new channels for students' social interaction behavior, this is only a necessary complement to the traditional teacher-student communication and cooperation. At this stage, it is not enough to replace face-to-face answering dilemmas between teachers and students. At the same time, the students' face-to-face talk and cooperation can promote their organizations to establish a good environment, cultivate students' excellent communication, expression and social ability. It is helpful for the students to increase the depth of research and discussion, promote the friendship between the students and improve their team integration and cooperation consciously. So it is worth for teachers to advocate with great effort.

According to the statistical data of college students' social interaction behavior, this study suggests: In addition to online answering questions, teachers should make full use of the classroom time or outside the classroom to communicate with students face-to-face. Meanwhile, teachers should listen carefully to the students' feelings and perceptions of the classroom teaching, answer all kinds of questions raised by the students patiently, provide targeted guidance for students to learn, work and live. After all, students should not only learn knowledge in colleges and universities, but also have many more important things to do. For example, they should be cultivated of good quality and right way of doing things. Various behaviors of college teachers will exert subtle influences on students' personality perfecting and thus play a significant role in personality education. So teachers must pay more attention and time to care about these students, give them more guidance and help both in their study and life.

For communication and cooperation with Blackboard, this study suggests that, teachers must do sufficient research on the communication and collaboration tools provided by 
Blackboard, make full use of the discussion board to propose hot topics, organize students to conduct asynchronous online communication. Through the collaborative tools, teachers should guide the students to participate in the lesson and discussion; with the help of group page, create a group study and exchange areas for students, so that students can carry out more personal learning, discussion, cooperation in groups and will not be affected by other students. Teachers can also send e-mails or messages to all or certain Blackboard users to communicate with them. In this way, whether students in class or out of class, they can communicate and collaborate easily through the face-to-face mode or online mode. This will promote the sharing of knowledge, and improve the effectiveness of teaching.

\subsection{About the Problem Solving Behavior}

The survey shows that, the students spend more time to review than preview through Blackboard. The number of students to do exercise, tests or other research study autonomously less than 50\%. This indicates that students' learning is passive, there still exists a larger gap in their autonomous learning, self-monitoring, adjusting their learning strategy and etc.

In the research process, our group members interviewed some students consciously about their learning habits, learning characteristics, learning behavior and other aspects. The interviewed students generally reflected that most of their review behavior after class is to complete the homework, or the teacher has specific requirements and commit to record the scores. Otherwise, many students pay rarely attention to the contents of the curriculum after class, not to mention the preview. Only when the time is close to the final examination, most of the students will $\log$ on the Blackboard frequently, download courseware and other learning materials, review teaching contents, do exercises and tests in order to pass the examination successfully with the help of more practice through online testing and other module.

About carrying out the teaching process management using Blackboard to improve the students' problem solving behavior, the authors suggest: On the one hand, teachers can make evaluation to be integrated into the students' daily learning process, set clear contents of preview, review, practice, testing and developing reading, propose unambiguous deadline of completion in Blackboard, ask students to understand their learning effect from targeted self-study, self-testing and self-evaluation. On the other hand, teachers can also use Blackboard function to provide "Adaptive release" or "Advanced adaptive release", create the teaching content adaptive issued rules and its advanced portfolio, control the contents released to all students or a specific user and group. For example, teachers can set up a rule for the students to view the follow-up contents only after they have completed a test and obtain the prescribed score. This can give better guides for the students to prepare lessons before class, review after class and do some other autonomous learning. It needs to be pointed out is that, teachers shall follow the tracks of students to visit each section of the Blackboard by using the statistical function, check the assignments and grasp the learning performance of students, control the learning process, integrate various evaluation data, and to provide evidence for the improvement of teaching in the whole process.

Finally, in view of the above research and interview results, the researchers think that, in local ordinary colleges and universities, teachers should pay more attention to college students, especially lower grade students, give them more learning process management and guidance. For many ordinary university students, they have learning enthusiasm and a strong sense of participation. But it is undeniable that, these students' learning initiative is weak, there also exist some problems in their learning habits and behavior, especially their self-management ability, planning ability and autonomous learning ability should be strengthened. In this case, it is very useful for teachers to provide more guidance and management consciously, even make some necessary rules, and organize the target 
management and learning process management together. This will no doubt have great advantages to help the students regulate their own learning behavior, and do more active analysis, application, reflection and innovation in their studies.

\section{Acknowledgements}

We wish to express our thanks to reviewers for their critical comments. This study is supported by the 2013 Education Research and Reform Project and Funding Project for Academic Human Resources Development (BPHR2014F03) in Beijing Union University.

\section{References}

[1] L.-Y.Liu, L.-F.Liu, Analysis and Research on the network learning behavior based on the interactive theory. Education for Chinese After-school. 9,23 (2012)

[2] I.Ajzen, The Theory of Planned Behavior. Organizational Behavior and Human Decision Processes.50,179 (1991)

[3] K.A.Hummel, H.Hlavacs. Anytime, Anywhere Learning Behavior Using a Web-Based Platform for a University Lecture. Proceedings of the SSGRR 2003 Winter Conference, (2003) January 6; L'Aquila, Italy

[4] Z.-H.Tian, Analysis on Behavior, Behavioral Sciences and Behaviorism. Journal of Hunan University (Social Science Edition).13,72 (1999)

[5] W.-H.Peng, Z.-K.Yang, K.-B.Huang, Analysis on network learning behavior and model study. China Educational Technology. 10,31 (2006)

[6] Q. Huang, "Application of Web Usage Mining in Personalized Web-based Education", Modern Educational Technology, vol. 14, no. 52, (2004).

[7] G. S. Fu and G. H. Wang, "Research on network learning behavior and effect based on data mining", eEducation Research, vol. 9, no. 53, (2014).

[8] L. Lv and Y. Zhang, "Current Status of Research in Network Learning Behavior Acquisition Based on Web-based Services", Open Education Research, vol. 15, no. 99, (2009).

[9] L. N. Yang and Z. J. Yan, "Empirical research on E-learning behavior from the perspective of information technology adoption", Distance Education in China, vol. 4, no. 36, (2011).

[10] Y. B. Li and S. N. Wu, "Investigation and research on network learning behavior of College Students", e-Education Research, vol. 11, no. 59, (2013).

[11] Z. Ji, "Online Learning Behavior of College Students: an Empirical Study", Distance Education in China, vol. 5, no. 59, (2013).

[12] J. W. Zhang and Y. Q. Sun, "The Psychological Issues of Multimedia and Network Based Learning”, Media in Foreign Language Instructional, vol. 2, no. 3, (2004).

[13] H. M. Sun, "Key issues study on the influence of the personality characteristics to network learning behavior", e-Education Research, vol. 10, no. 50, (2012).

[14] Q. H. Pan, "Research on Web-based Autonomous Learning Forms - the Basis of Learning Behavior in Web2.0 Environment", Distance Education in China, vol. 12, no. 35, (2012).

[15] H. Y. Yan, "The main influence factors of network information retrieval behavior", Journal of Information, vol. 4, no. 94, (2004).

[16] F. Y. Huang and J. Xu, "The Review of the Foreign Study on Information Retrieval Behavior of Users from”, Library Development, vol. 3, no. 86, (2008).

[17] J. J. Shang, H. L. Li and A. M. Dong, "Research on College Students' Internet Behavior Based on the Theory of Planned Behavior", Modern Distance Education Research, vol. 3, no. 108, (2014).

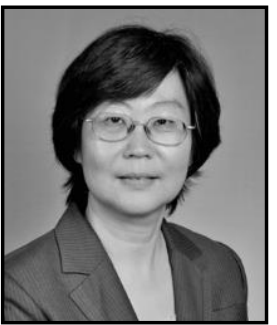

Li Zheng received her Master degree of Celestial mechanics and Astrometry (1991) from Beijing Normal University. Now she is a professor of Computer application, Business College of Beijing Union University, China. Her current research interests include eBusiness and the informatization of Education. 


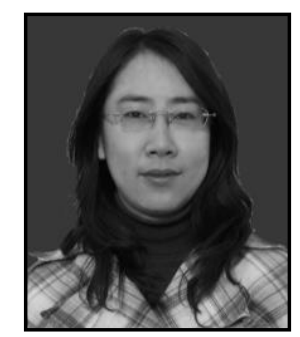

Yinghua NIU received her Master degree of statistics (2006) from Capital University of Economics and Business. Now she is engaged in the educational administration, Business College of Beijing Union University, China. Her current research interests include Economics, education and teaching. 